\title{
The effects of cumulative forest disturbance on streamflow in a large watershed in the central interior of British Columbia, Canada
}

\author{
M. Zhang and X. Wei \\ Department of Earth and Environmental Science, The University of British Columbia (Okanagan campus), \\ 3333 University Way, Kelowna, British Columbia, Canada
}

Correspondence to: X. Wei (adam.wei@ubc.ca.)

Received: 17 February 2012 - Published in Hydrol. Earth Syst. Sci. Discuss.: 5 March 2012

Revised: 5 June 2012 - Accepted: 7 June 2012 - Published: 11 July 2012

\begin{abstract}
The Baker Creek watershed $\left(1570 \mathrm{~km}^{2}\right)$, situated in the central interior of British Columbia, Canada, has been severely disturbed by both logging and natural disturbance, particularly by a recent large-scale mountain pine beetle (MPB) infestation (up to $2009,70.2 \%$ of the watershed area had been attacked by MPB) and subsequent salvage logging. The concept of equivalent clear-cut area (ECA) was used to indicate the magnitude of forest disturbance, with consideration of hydrological recovery following various types of disturbance (wildfire, logging and MPB infestation), cumulated over space and time in the watershed. The cumulative ECA peaked at $62.2 \%$ in 2009. A combined approach of statistical analysis (i.e. time series analysis) and graphic method (modified double mass curve) was employed to evaluate the impacts of forest disturbance on hydrology. Our results showed that severe forest disturbance significantly increased annual mean flow. The average increment in annual mean flow caused by forest disturbance was $48.4 \mathrm{~mm} \mathrm{yr}^{-1}$, while the average decrease in annual mean flow caused by climatic variability during the same disturbance period was $35.5 \mathrm{~mm} \mathrm{yr}^{-1}$. The opposite changes in directions and magnitudes clearly suggest an offsetting effect between forest disturbance and climatic variability, with the absolute influential strength of forest disturbance $(57.7 \%)$ overriding that from climate variability $(42.3 \%)$. Forest disturbance also produced significant positive effects on low flow and dry season (fall and winter) mean flow. Implications of our findings for future forest and water resources management are discussed in the context of long-term watershed sustainability.
\end{abstract}

\section{Introduction}

Forests play an important role in the water cycle by influencing rainfall interception, evapotranspiration, and soil infiltration and storage. Forest disturbances such as logging, wildfire, and insect infestation can effect streamflow by altering its regime (i.e. magnitude, frequency, timing, duration and rate of change). Numerous studies on the hydrological impacts of logging have been conducted on small watersheds (less than $100 \mathrm{~km}^{2}$ ), using the paired-watershed experimental approach, and those studies have shown that forest harvesting can significantly increase annual mean and peak flows, and change dry season low flow (Stednick, 1996; Neary et al., 2003; Bruijnzeel, 2004; Moore and Wondzell, 2005). However, the research on impacts of forest disturbance on hydrology in large watersheds $\left(>1000 \mathrm{~km}^{2}\right)$ is limited (Wei and Zhang, 2010a; Vose et al., 2011), and the results are inconsistent (Ring and Fisher, 1985; Buttle and Metcalfe, 2000; Costa et al., 2003; Tuteja et al., 2007; Wei and Zhang, 2010b). In spite of limited research, the topic of the forest disturbance-hydrology relationship in large watersheds has received growing attention, mainly because of the increasing need to support natural resources planning and management at large spatial scales.

A large watershed can be shown to have various types of forest disturbance that are cumulative over both space and time. These disturbances interactively affect watershed hydrology, and their effects tend to be cumulative. The interactive effects of various forest disturbances on hydrology in large watersheds are seldom examined, mainly due to lack of an indicator for representing and integrating various types of forest disturbance, as well as great difficulty in separating 
the effects of forest disturbance from the influence of climatic variability (Wei and Zhang, 2010a).

A suitable forest disturbance indicator for a large watershed should not only represent all types of disturbance and ranges of their intensity, but also include cumulative forest disturbance history and subsequent recovery processes following disturbance over space and time (Wei and Zhang, 2010a). ECA (equivalent clear-cut area), an indicator widely used in British Columbia and Alberta, is defined as the area that has been clear-cut, with a reduction factor to account for hydrological recovery due to forest regeneration after disturbance (BCMFR, 1999). Harvest blocks, agricultural areas, residential development, and roads can all be expressed as ECA. Research has established the relationships between vegetation growth (ages or tree heights) following disturbance and hydrological recovery rates, so that ECA can be derived spatially and temporally in a watershed (Hudson, 2000; Talbot and Plamondon, 2002; Winkler et al., 2005; Lewis and Huggard, 2010). The ECA has already been successfully used in British Columbia, Canada, to test watershed-scale forest disturbances and their effects on various watershed processes including aquatic habitat (Chen and Wei, 2008), hydrology (Lin and Wei, 2008) and aquatic biology (Whitaker et al., 2002; Jost et al., 2008). In spite of growing recognition of ECA, its utility in representing various types of forest disturbance (including mountain pine beetle infestation, harvesting, and fire) in a single large watershed for hydrological studies has not been applied as far as we know.

Another barrier for large watershed studies is the lack of a robust research methodology. Forest disturbance and climatic variability are viewed as two major drivers interactively influencing streamflow in large forested watersheds (Buttle and Metcalfe, 2000; Sharma et al., 2000; Blöschl et al., 2007; Ma et al., 2010; Wei and Zhang, 2010b). The greatest challenge is how to separate their relative contributions to hydrology (Zhang et al., 2008; Wang et al., 2009; Zheng et al., 2009; Wei and Zhang, 2010b). Physically-based hydrological modeling is commonly used to assess the relative effects of climate variability and forest change on hydrology (Tuteja et al., 2007; Juckem et al., 2008; Zégre et al., 2010; Zhao et al., 2010). However, this modeling approach is only suitable for the watersheds that are well monitored with extensive, longterm data available on vegetation, soil, topography, land use, hydrology and climate (Wei and Zhang, 2010a, b). Moreover, it requires time-consuming model calibration and validation. Advanced statistical methods (e.g. non-parametric tests, regression analysis, and time series analysis) combined with graphical methods (double mass curves, single mass curves, and flow duration curves) are promising alternatives in view of their limited data requirements and abilities to generate reliable inferences (Buttle and Metcalfe, 2000; Lin and Wei, 2008; Wei and Zhang, 2010b).

Lack of suitable watersheds can also constrain forest hydrological studies at large spatial scales. In order to detect the cumulative effects of forest disturbance on hydrology, a large watershed must experience significant forest disturbance. It must also have long-term data on forest disturbance, as well as climatic and hydrological data with a sufficiently long period of no or limited forest disturbance as a comparable reference or control period. Given the fact that the majority of large watersheds are poorly monitored or regulated, it is rather challenging to find suitable study watersheds.

The Baker Creek watershed in the central interior of British Columbia, Canada, has been severely disturbed by a large-scale mountain pine beetle (MPB) infestation and subsequent salvage logging in the last $10 \mathrm{yr}$. Up to $2009,70.2 \%$ of the watershed area had been attacked by MPB, and cumulative logged area accounted for about $41.4 \%$ of the total watershed area. The forest disturbance level in terms of ECA was up to $62.2 \%$ in 2009. The significant forest disturbances along with long-term data on climate, hydrology, and forest disturbance history provide a unique opportunity to examine the possible cumulative effects of forest disturbance on hydrology at a large spatial scale. Early work by Alila et al. (2007) used the DHSVM model to evaluate the hydrological impacts of different forest logging scenarios in the Baker Creek watershed. However, their analysis only included forest logging without addressing the cumulative hydrologic effect of various types of forest disturbance. In this study, we used our non-modeling methodology to study the cumulative effects of forest disturbance on the hydrology of the Baker Creek watershed. The methodology combines statistical analysis (i.e. time series analysis) with graphical methods (i.e. modified double mass curves) (Wei and Zhang, 2010b). The major objectives of this study were: (1) to assess the cumulative effects of forest disturbance on annual mean and low flows; and (2) to quantify the relative contributions of forest disturbance and climatic variability to annual mean flow in the Baker Creek watershed.

\section{Watershed description}

The Baker Creek, about $114 \mathrm{~km}$ in length and with a drainage area of $1570 \mathrm{~km}^{2}$, flows into the Fraser River in Quesnel in the central interior of B.C., Canada (Fig. 1). Most of the watershed is a plateau. Elevations for the watershed range from $475 \mathrm{~m}$ at the river mouth to $1500 \mathrm{~m}$ in the headwaters, with a median elevation of $1100 \mathrm{~m}$. Areas at higher elevations and the valley bottom above the canyon section are characterized by volcanic bedrock. Unconsolidated sediments are dominant at middle elevations, while the middle or canyon section of the watershed is a complex of metasedimentary and volcanic rock.

The climate in the Baker Creek watershed is relatively cool and dry. As shown in Fig. 2, December and January always have the lowest temperatures, while July and August have the highest temperatures. The long-term average monthly maximum temperature can reach $20.4^{\circ} \mathrm{C}$ in 


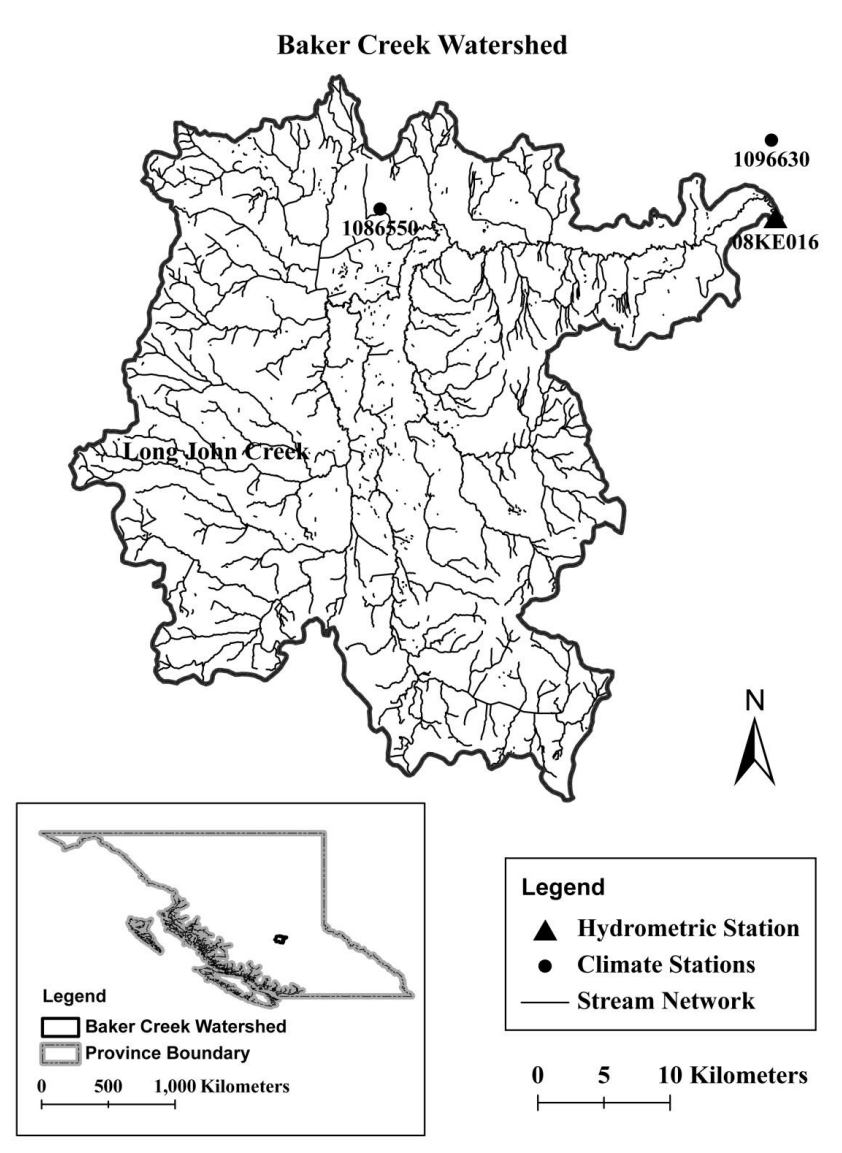

Fig. 1. Location of the study watershed in the central interior of British Columbia, Canada.

July, while the average monthly minimum temperature is $-14.4^{\circ} \mathrm{C}$ in January. Annual watershed areal precipitation ranges from $360 \mathrm{~mm}$ (in 1987) to $738 \mathrm{~mm}$ (in 1982), with an average of $542 \mathrm{~mm}$, of which $34 \%$ is from snow during the winter season (November to March).

According to the biogeoclimatic ecosystem classification (BEC) system, this watershed is primarily located within the Sub-Boreal-Pine-Spruce (SBPS) biogeoclimatic zone featured with lodgepole pine (Pinus contorta) and white spruce (Picea glauca) (BCMFR, 2012). The Sub-Boreal-Spruce (SBS) and the Montane-Spruce (MS) biogeoclimatic zones can also be found at middle and higher elevations, respectively.

\section{Data and methods}

\subsection{Data}

There is one active hydrometric station in the Baker Creek watershed (Station ID: 08KE016, Baker Creek at Quesnel) with records dating back to 1964 . Hydrological data including daily flows and monthly flows from 1964 to 2009 were obtained from this station. According to the historical

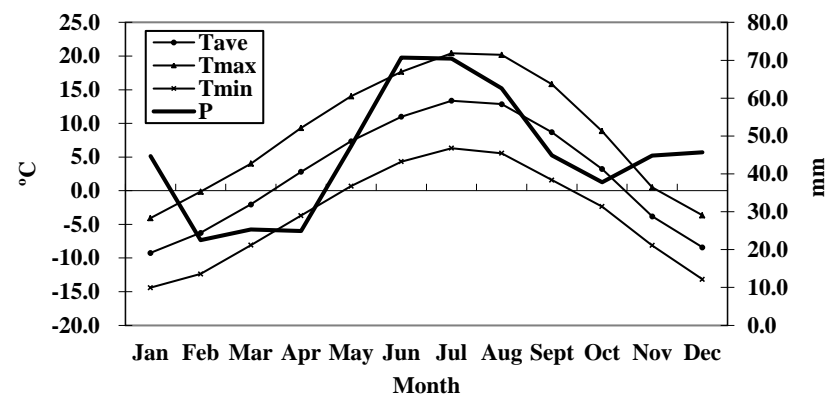

Fig. 2. Long-term (1964 to 2009) average monthly temperature $\left({ }^{\circ} \mathrm{C}\right)$ and precipitation $(\mathrm{mm})$.

records, the annual streamflow hydrographs can be divided into four periods: spring (April-June), summer (JulyAugust), fall (September-October) and winter (NovemberMarch) (Fig. 3). The annual mean flow is highly variable, ranging between $24 \mathrm{~mm}$ in 1988 and $179 \mathrm{~mm}$ in 2007, with an average of $103.3 \mathrm{~mm}$. Streamflow usually reaches peaks in late April or May from snowmelt, and the streamflow during the snowmelt season accounted for $68 \%$ of the annual total.

Climate data used in this study such as monthly mean, maximum and minimum temperature, and precipitation are from ClimateWNA dataset. ClimateWNA is a gridded climate dataset for Western North America which downscales and integrates monthly and annual historical climate data (1901-2009) (Mitchell and Jones, 2005; Mbogga et al., 2009). Given large spatial variations in climate and precipitation, in particular due to topographic effect, gridded monthly climate data from ClimateWNA were derived with a resolution of $10 \mathrm{~km} \times 10 \mathrm{~km}$ and then aggregated to generate monthly climate data series for the whole watershed.

GIS-based data on forest disturbance history for the study watershed were derived by use of ArcGIS 9.2 from two provincial databases: Cutblocks 2010 and VRI (Vegetation Resources Inventory) 2010, both developed and maintained by the B.C. Ministry of Forests, Lands and Natural Resources Operations. The Cutblocks 2010 database combines logging information from both the B.C. Ministry of Forests, Lands and Natural Resources Operations and Forest Industries up to 2009. It contains complete records of cutblock sizes and logged years, but detailed vegetation information was not included. The VRI 2010 database records various disturbance information (i.e. fire, infestation, and logging) and detailed vegetation descriptions up to 2009. However, its records on logging are incomplete due to delayed submissions from forestry companies. Thus, both datasets are complementary and were used in this study. Data from the two databases were overlaid and analyzed in ArcGIS 9.2 to generate complete records on quantitative forest disturbance history for the study watershed. 


\subsection{Methods}

\subsubsection{Quantification of forest disturbance level}

Logging, fire, and MPB infestation are recognized as three major forest disturbance types in the Baker Creek watershed. Between the 1960s and 1970s, forest disturbances were limited except for a large burn in 1961 that occurred in the Long John Creek-Wentworth Lake area, a tributary to the study watershed, and which burned about $0.3 \%$ of the watershed area. The cumulative area burned by wildfire was less than $1 \%$ up to 2009. The MPB disturbance was rare before 2000 . Nevertheless, it has become dominating after its large-scale outbreak in 2003, with $17.3 \%$ of the watershed area affected in that year. $85 \%$ of forest stands are pine-leading and $83 \%$ of them have been attacked by MPB. Up to 2009, forests attacked by MPB came up to $70.2 \%$ of the total watershed area. Logging is the most dominant human-being caused disturbance after 1970. Large-scale logging activities occurred in two periods (1975-1980 and 1989-2009). The most intensive logging took place between 2001 and 2009 as a result of salvage logging in response to large-scale MPB outbreak; $23.8 \%$ of the watershed (14\% salvage logged) was harvested during that period with an average clear-cut rate of $2.6 \%$ per year. From 1961 to 2009, the cumulative logged area accounted for $41.4 \%$ of the total watershed area (Fig. 5a). Thus, the Baker Creek watershed has been disturbed by severe MPB infestation and subsequent salvage logging in the recent $10 \mathrm{yr}$.

Since all kinds of forest disturbance are cumulative over both space and time in the study watershed, ECA was used in this study as an integrated indicator that combines all types of forest disturbance, spatially and temporally, with consideration of vegetation and hydrological recovery following disturbance. For example, an ECA coefficient of $100 \%$ means no hydrological recovery in a disturbed forest stand, while an ECA coefficient of $0 \%$ indicates a $100 \%$ hydrological recovery. However, the generation of ECA coefficients for each type of disturbance is challenging because hydrological recovery is determined by various factors, mainly including disturbance type, climate, and tree species (Hudson, 2000; Talbot and Plamondon, 2002).

The relationship between vegetation growth, represented by ages or tree heights following logging, and hydrological recovery rates was generally used to estimate ECA after logging for different tree species, mainly spruce and lodgepole pine forests, in the watershed assessment (BCMFR, 1999). Given that those two species are dominant in the study watershed, we developed a relationship between age/height and hydrological recovery for those two tree species for logging. For MPB infestation, Lewis and Huggard (2010) have developed a model to quantify the effects of MPB infestation on ECA calculation based on their monitoring in different biogeoclimatic zones. Based on their studies and inputs from local forest hydrologists, we also developed

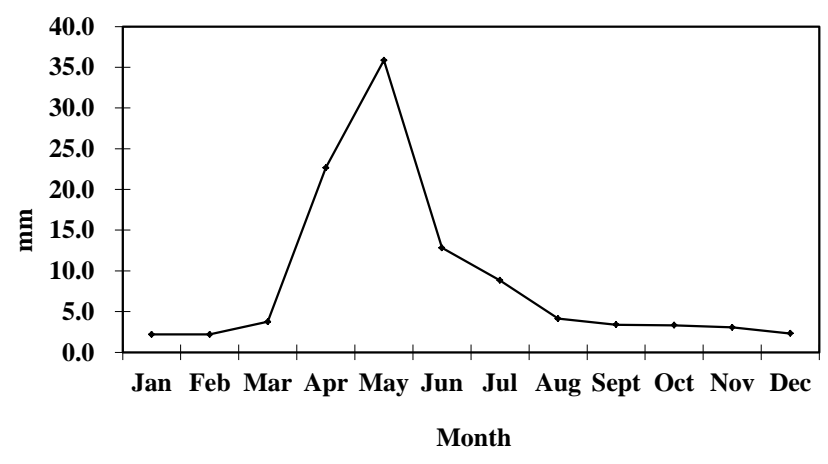

Fig. 3. Average monthly flows in the Baker Creek watershed.

relationships between tree ages/heights and hydrological recovery in SBPS, SBS, and MS biogeoclimatic zones for the MPB killed forest stands. The hydrological impact of MPB infestation on forests is different from that of logging. Since dead trees remain in stands, the hydrological function of dead trees is not as completely damaged as removal of trees by logging (Winkler et al., 2008). Moreover, the understory beneath MPB attacked stands and other trees not attacked by MPB at the overstorey can also intercept and transpire water. Thus, the alteration of hydrology due to MPB infestation was much lower than for clear-cut areas, especially within 1-2 yr after attacks. However, as dead trees lose their canopy over time, the hydrological effect of MPB attack is increased and then decreased with regeneration of young trees. For example, the ECA coefficient for the forest stand in the SBS/SBPS zone is only about $15 \%$ one year after an MPB attack, reaches the maximum of $75 \% 18-20 \mathrm{yr}$ later, and then drops to $10 \%$ after $60 \mathrm{yr}$ (Lewis and Huggard, 2010). Figure 4 provides time series of ECA coefficients for logging, fire, and MPB, which were used to estimate ECA data series for each forest stand based on their disturbed area (e.g. annual clearcut area) derived from historic disturbance records.

Any forest stand in the study watershed could actually be disturbed by a single disturbance agent or by multiple types of disturbance, chronologically or simultaneously. In order to calculate long-term ECA for the whole watershed, disturbed forest stands in the Baker Creek watershed were classified into 5 groups according to the disturbance history from the two datasets, Cutblocks 2010 and VRI 2010. They are described as below:

1. forest stands disturbed by logging;

2. forest stands disturbed by MPB;

3. forest stands disturbed by fire;

4. forest stands disturbed by both logging and fire;

5. forest stands disturbed by both logging and MPB.

Annual ECA data series for each group was calculated individually and then summed to derive annual ECA data for 


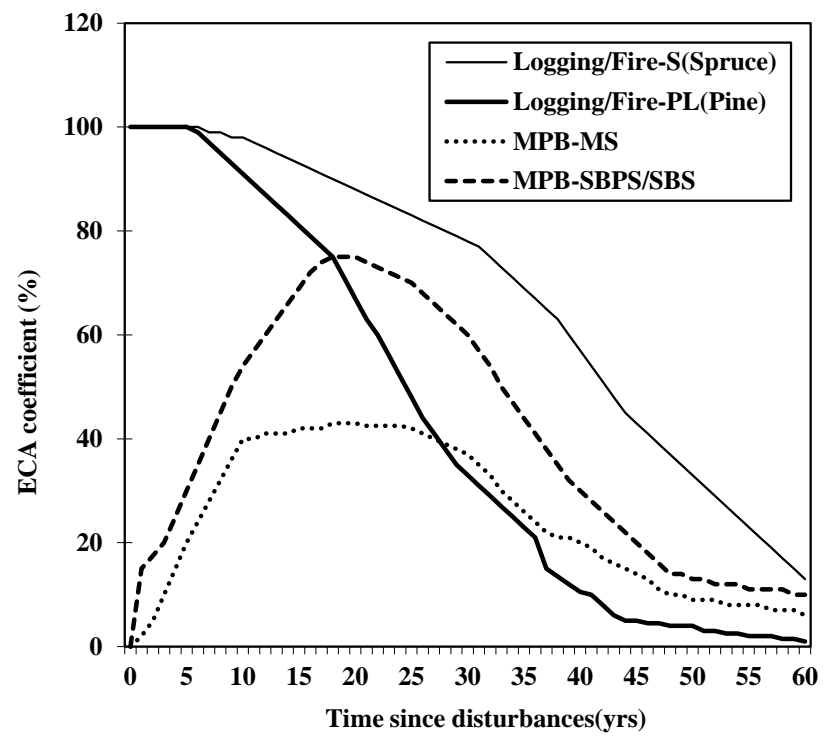

Fig. 4. Equivalent clear-cut area (ECA) coefficients for the Baker Creek watershed.

all disturbances in the watershed. As shown in Fig. 5b, cumulative ECA was about $1 \%$ in 1975 , which was then slowly increased to $10.4 \%$, and jumped from $22.4 \%$ in 2002 to $62.2 \%$ in 2009 due to salvage logging after the large-scale MPB outbreak in 2003. Up to 2009, the cumulative ECA of logging and salvage logging in response to MPB attack were $24.4 \%$ and $22.6 \%$, respectively. The cumulative ECA of the MPB attack without logging was $14.8 \%$ (Fig. 6).

\subsubsection{Trend analysis}

Trend analysis was conducted first to provide background information on temporal dynamics in hydrological and climatic data series over the study period for a better understanding of hydrological variations caused by different factors. Hydrological variables involved in trend analysis included mean flow and 7-day low flow (lowest average flow over a 7-day period) on annual and seasonal (spring, summer, fall, and winter) scales. Precipitation trends were also viewed at annual and seasonal scales. Many studies show an obvious shift in the Pacific Decadal Oscillation (PDO) regimes from cool phase to warm phase around 1977 (Mantua and Hare, 2002; Fleming et al., 2007). This shift caused a significant effect on climate in Pacific North America, with more precipitation and lower temperature in the cool phase (1946-1976) than in the warm phase (1977-1990s) (Kiffney et al., 2002; St. Jacques et al., 2010). To exclude the effect of this climate regime shift on streamflow, trend analysis was conducted not only over the whole study period (19642009), but also under different PDO regimes (1964-1976 and 1977-2009). Non-parametric tests, including Mann-Kendall tau and Spearman's rho (Berryman et al., 1988; Burn and Hag Elnur, 2002; McCabe and Wolock, 2002), were applied
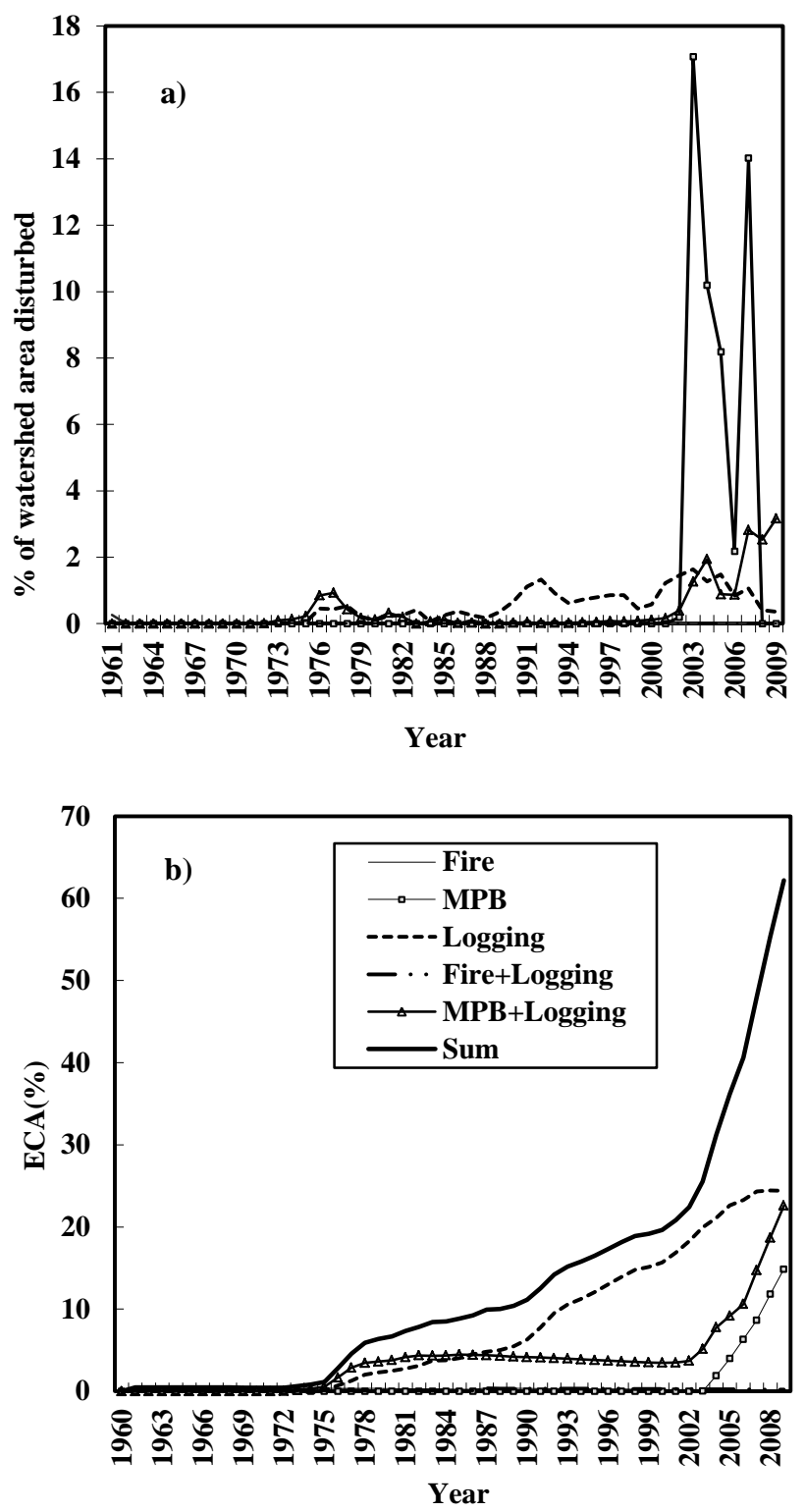

Fig. 5. Cumulative equivalent clear-cut area (ECA) from 1961 to 2009 .

in the trend detection, and changes with a significance level of $5 \%$ for each data series during the three different periods were identified.

\subsubsection{Correlation analysis}

Cross-correlation in time series analysis was performed to detect the relationships between hydrological variables (mean flow and 7-day low flow on annual and seasonal scales) and annual ECA series. Cross-correlation analysis is found to be an effective approach to investigate the relationships among environmental variables because it can address autocorrelation issues in data series and identify the lagged 
causality between two data series (Jassby and Powell, 1990; Lin and Wei, 2008; Zhou et al., 2010). All hydrological data series along with ECA data series were pre-whitened to remove autocorrelations by fitting ARIMA (Autoregressive Integrated Moving Average) models. White noises or model residuals from ARIMA models with best performance, in terms of achievements of model stationarity and coefficient of determination $\left(R^{2}\right)$, were selected for cross-correlations (Lin and Wei, 2008).

\subsubsection{Quantification of forest disturbance effect on annual mean flow}

For a large forested watershed, climatic variability and forest disturbance are two primary drivers of hydrological variation. In order to separate the effects of climate variability and forest disturbance on annual mean flow, the "modified double mass curve" developed by Wei and Zhang (2010b) was used to eliminate the influence of climatic variability on annual mean flow. According to the annual watershed water balance, streamflow is determined by the difference between precipitation and evapotranspiration, because change in soil water storage over an annual scale can be assumed to be constant and minor (Zhang et al., 2001). Thus, we firstly defined an integrated climatic index named "effective precipitation" (Pe) for streamflow generation, referring to the difference between precipitation and evapotranspiration (Wei and Zhang, 2010b). The annual evapotranspiration was estimated by Eq. (1) (Zhang et al., 2001), a modification of Budyko's evaporation made by adding the additional vegetation factor $w$, which has been proven to be a sound solution for watershed scale evapotranspiration estimation (Donohue et al., 2007; Li et al., 2007; Oudin et al., 2008). Given the limited long-term data in this large watershed, the Hargreaves equation (Hargreaves and Samani, 1985) was applied to compute potential evapotranspiration (Eq. 2). It requires only mean, minimum and maximum air temperature, and extraterrestrial radiation (Shuttleworth, 1993; Sankarasubramanian et al., 2001), which are available for the study watershed.

$$
E=P\left[1+w\left(E_{0} / P\right)\right] /\left[1+w\left(E_{0} / P\right)+P / E_{0}\right]
$$

and

$E_{0}=0.0023 \cdot \mathrm{Ra} \cdot\left[\left(\left(T_{\max }+T_{\min }\right) / 2+17.8\right)\right] \cdot\left(T_{\max }-T_{\min }\right)^{0.5}(2)$

where, $\mathrm{Ra}$ is extraterrestrial radiation; $T_{\max }$ is mean maximum temperature in ${ }^{\circ} \mathrm{C} ; T_{\min }$ is mean minimum temperature in ${ }^{\circ} \mathrm{C}$; $P$ is precipitation; $E$ is evapotranspiration; $E_{0}$ is potential evapotranspiration; and $w$ is plant-available water coefficient.

A modified double mass curve was created then by plotting accumulated annual mean flow versus accumulated annual effective precipitation. In this way, the climatic effect on annual mean flow can be eliminated. The basic assumption underlying this modified double mass curve (MDMC) is that there is a linear relation between variation in annual mean flow and that in effective precipitation (Zheng et al., 2009; Wei and Zhang, 2010b). In periods without or with only minor forest disturbance (namely the reference period), a straight line is expected which serves as a baseline describing the linear relation between annual mean flow and annual effective precipitation; a break in this curve indicates the change of annual mean flow caused by the factors other than climatic variability, for example, forest disturbance or land-use change. In other words, a step change or regime shift occurs in the slope of the modified double mass curve, and the slope before the break is different from that afterwards. Both the CUSUM control chart (the cumulative sum control chart) and the Mann-Whitney U-test were applied to determine the breakpoint with statistical significance. The CUSUM control chart, a widely used change point detection method, was applied to identify the breakpoints of statistical significance (Barnard, 1959). Then the study period was divided into the reference period and disturbance period using the significant breakpoint. The Mann-Whitney U-test (Siegel, 1957) was then used to further confirm if there was a step change of statistical significance in the slope of MDMC through comparison of slope in the reference period with that in the disturbance period.

Finally, the difference between the observed values and the values predicted by the baseline during the disturbance period in the MDMC is the estimated cumulative effect of forest disturbance on annual mean flow, as compared with undisturbed conditions. Once annual mean flow deviation attributed to forest disturbance $\left(\Delta Q_{\mathrm{f}}\right)$ is estimated, the deviation resulting from climatic variability can then be computed by the following equation:

$\Delta Q_{\mathrm{c}}(t)=\Delta Q(t)-\Delta Q_{\mathrm{f}}(t)$

where, $\Delta Q(t), \Delta Q_{\mathrm{c}}(t)$, and $\Delta Q_{\mathrm{f}}(t)$ represent annual mean flow deviation, annual mean flow deviation attributed to climate variability, and annual mean flow deviation attributed to forest disturbance for the $t$ th yr, respectively.

\section{Results}

\subsection{Long-term changes in hydrological and climatic variables}

Over the whole study period between 1964 and 2009, there was a significant downward trend in winter precipitation, while no statistically significant trends were detected in other hydrological variables and climatic variables (Table 1). However, separation of the study period into different PDO periods revealed no significant trend in annual precipitation from 1977 to 2009, but a significant upward trend for annual mean flow (Table 1). The inconsistent trends between annual precipitation and annual mean flow suggest that something other than climatic variability altered streamflow. Since climatic 


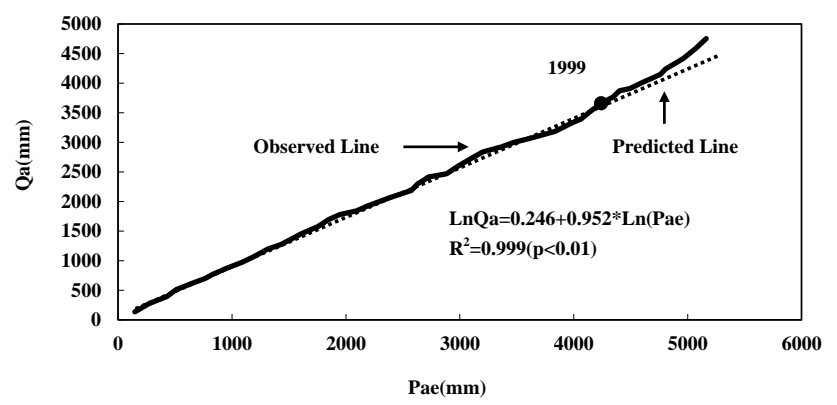

Fig. 6. Modified double mass curve.

variability and forest disturbance are regarded as the two main drivers for inter-annual mean flow changes, the increment in annual mean flow during the period of 1977 to 2009 was judged to be caused by forest disturbance. This suggests that forest disturbance and climate have interactively influenced streamflow. It further highlights that the effect of climatic variability on streamflow must be removed before the effects of forest disturbance on hydrology can be quantified.

\subsection{Correlations between hydrological variables and forest disturbance level}

As suggested by the cross-correlation analysis, annual, winter, and fall mean flows were significantly and positively correlated with ECA (Table 2). Also, there were significantly positive correlations between annual 7-day low flow and ECA.

\subsection{Forest disturbance effect on annual mean flow}

Figure 6 displays the modified double mass for the study watershed, where accumulated annual mean flow is plotted against accumulated annual effective precipitation. According to the CUSUM control chart change point analysis of slopes in Fig. 6, a significant breakpoint in 1999 was detected at $\alpha=0.05$ (Table 3). The Mann-Whitney U-test further confirmed the statistical significance of this breakpoint by comparing the median of slopes in the period from 1964 to 1998 with that from 1999 to 2009. Thus, we defined the reference period as between 1964 and 1998, while the disturbance period was from 1999 to 2009. As shown in Fig. 6, a straight line (linear relationship) was observed between accumulated annual mean flow and accumulated annual effective precipitation in the period from 1964 to 1998 . After 1999, the observed line started to deviate from the original line (predicted line), suggesting that more annual streamflow was generated than predicted. The differences between observed accumulated annual mean flow and predicted values from 1999 to 2009 are referred to as accumulated annual mean flow deviations attributed to forest disturbance. Annual mean flow deviations attributed to forest disturbance were then calculated accordingly. As shown in Fig. 7a and b, annual mean flow
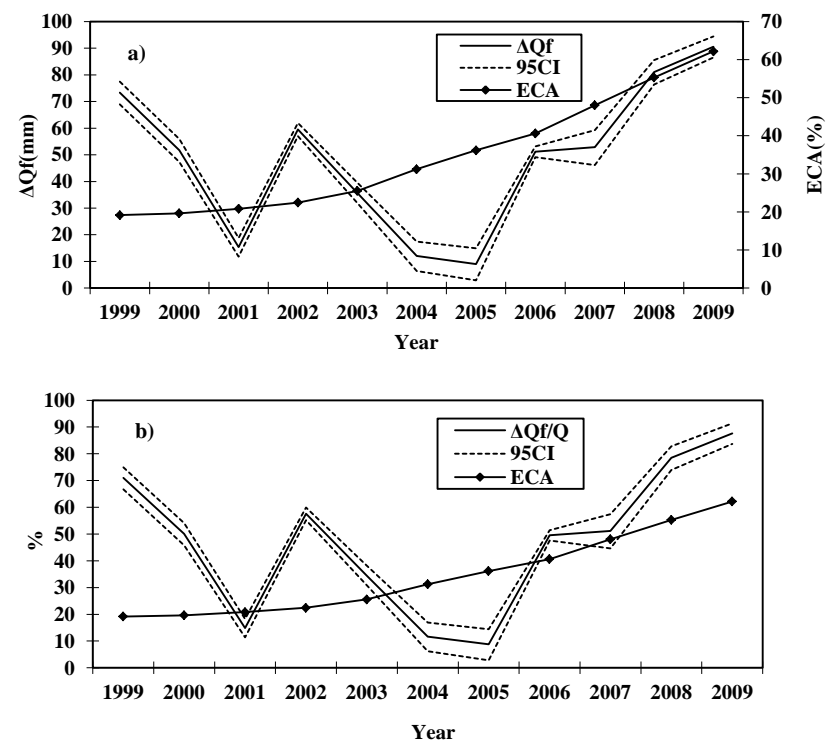

Fig. 7. (a) Annual mean flow deviation attributed to forest disturbance in $\mathrm{mm}$; (b) annual mean flow deviation attributed to forest disturbance in percentage.

deviations attributed to forest disturbance ranged from $9 \mathrm{~mm}$ ( $8.9 \%$ of long-term annual mean flow) to $91 \mathrm{~mm}(87.6 \%$ of long-term annual mean flow), with an average of $48.4 \mathrm{~mm}$ (46.9\% of long-term annual mean flow). Meanwhile, ECA experienced a significant increase from $19.2 \%$ in 1999 to $62.2 \%$ in 2009.

\subsection{Relative contributions of climatic variability and forest disturbance on annual mean flow}

In order to explore the temporal dynamic of the hydrological impact of forest disturbance, the whole study period was divided into three phases according to forest disturbance level: 1964 to 1989 (Phase 1, ECA $\leq 10 \%$ ), 1990 to 1998 (Phase 2, 10\% $\leq \mathrm{ECA} \leq 20 \%$ ), and 1999 to 2009 (Phase 3, ECA $\geq 20 \%$ ). Table 4 summarizes the average annual mean flow deviation and its components in different phases. In Phase 1, with an average ECA of $3.7 \%$, average annual mean flow deviation attributed to forest disturbance was $-0.8 \mathrm{~mm} \mathrm{yr}^{-1}$, which rose to $9.2 \mathrm{~mm} \mathrm{yr}^{-1}$ in Phase 2 and sharply increased to $48.4 \mathrm{~mm} \mathrm{yr}^{-1}$ (equivalent to $46.9 \%$ of average annual mean flow) in Phase 3. Meanwhile, the average annual mean flow deviations attributed to climate variability in Phase 1, Phase 2, and Phase 3 were $-4.8,-13.3$, and $-35.5 \mathrm{~mm}$, respectively. As shown in Table 4 , forest disturbance and climatic variability affected streamflow in opposite directions. Forest disturbance increased streamflow, while climatic variability decreased it over the study period.

Table 5 demonstrates the relative contributions of forest disturbance and climatic variability on annual mean flow variation. The impacts of forest disturbance and climate variability on annual mean flow were dynamic. The influence of 
Table 1. Trends in hydrological and climatic variables from 1964 to 2009.

\begin{tabular}{|c|c|c|c|c|c|c|}
\hline \multirow{2}{*}{ Variables } & \multicolumn{2}{|c|}{ 1954-2009 } & \multicolumn{2}{|c|}{ 1954-1976 } & \multicolumn{2}{|c|}{ 1977-2009 } \\
\hline & Mann-Kendall tau & Spearman rho & Mann-Kendall tau & Spearman rho & Mann-Kendall tau & Spearman rho \\
\hline Annual $Q$ & $\begin{array}{l}0.01 \\
(p=0.89)\end{array}$ & $\begin{array}{l}0.05 \\
(p=0.70)\end{array}$ & $\begin{array}{l}-0.23 \\
(p=0.08)\end{array}$ & $\begin{array}{l}-0.25 \\
(p=0.20)\end{array}$ & $\begin{array}{l}0.25^{*} \\
(p=0.04)\end{array}$ & $\begin{array}{l}0.39^{*} \\
(p=0.03)\end{array}$ \\
\hline Winter $Q$ & $\begin{array}{l}0.08 \\
(p=0.48)\end{array}$ & $\begin{array}{l}0.14 \\
(p=0.18)\end{array}$ & $\begin{array}{l}-0.10 \\
(p=0.45)\end{array}$ & $\begin{array}{l}-0.15 \\
(p=0.55)\end{array}$ & $\begin{array}{l}0.12 \\
(p=0.14)\end{array}$ & $\begin{array}{l}0.19 \\
(p=0.30)\end{array}$ \\
\hline Spring $Q$ & $\begin{array}{l}-0.02 \\
(p=0.82)\end{array}$ & $\begin{array}{l}-0.01 \\
(p=0.89)\end{array}$ & $\begin{array}{l}0.10 \\
(p=0.45)\end{array}$ & $\begin{array}{l}0.17 \\
(p=0.42)\end{array}$ & $\begin{array}{l}0.19 \\
(p=0.20)\end{array}$ & $\begin{array}{l}0.30 \\
(p=0.15)\end{array}$ \\
\hline Summer $Q$ & $\begin{array}{l}-0.04 \\
(p=0.75)\end{array}$ & $\begin{array}{l}-0.06 \\
(p=0.65)\end{array}$ & $\begin{array}{l}-0.21 \\
(p=0.10)\end{array}$ & $\begin{array}{l}-0.26 \\
(p=0.18)\end{array}$ & $\begin{array}{l}0.04 \\
(p=0.83)\end{array}$ & $\begin{array}{l}0.05 \\
(p=0.82)\end{array}$ \\
\hline Fall $Q$ & $\begin{array}{l}0.02 \\
(p=0.82)\end{array}$ & $\begin{array}{l}0.03 \\
(p=0.78)\end{array}$ & $\begin{array}{l}-0.10 \\
(p=0.45)\end{array}$ & $\begin{array}{l}-0.21 \\
(p=0.25)\end{array}$ & $\begin{array}{l}0.05 \\
(p=0.62)\end{array}$ & $\begin{array}{l}0.08 \\
(p=0.65)\end{array}$ \\
\hline Annual $P$ & $\begin{array}{l}-0.15 \\
(p=0.15)\end{array}$ & $\begin{array}{l}-0.20 \\
(p=0.18)\end{array}$ & $\begin{array}{l}-0.08 \\
(p=0.58)\end{array}$ & $\begin{array}{l}-0.11 \\
(p=0.70)\end{array}$ & $\begin{array}{l}0.03 \\
(p=0.88)\end{array}$ & $\begin{array}{l}0.05 \\
(p=0.89)\end{array}$ \\
\hline Winter $P$ & $\begin{array}{l}-0.19^{*} \\
(p=0.04)\end{array}$ & $\begin{array}{l}-0.30^{*} \\
(p=0.02)\end{array}$ & $\begin{array}{l}0.21 \\
(p=0.10)\end{array}$ & $\begin{array}{l}0.29 \\
(p=0.15)\end{array}$ & $\begin{array}{l}0.17 \\
(p=0.28)\end{array}$ & $\begin{array}{l}0.2 \\
(p=0.23)\end{array}$ \\
\hline Spring $P$ & $\begin{array}{l}-0.03 \\
(p=0.78)\end{array}$ & $\begin{array}{l}-0.05 \\
(p=0.70)\end{array}$ & $\begin{array}{l}-0.07 \\
(p=0.65)\end{array}$ & $\begin{array}{l}-0.12 \\
(p=0.64)\end{array}$ & $\begin{array}{l}-0.05 \\
(p=0.62)\end{array}$ & $\begin{array}{l}-0.07 \\
(p=0.70)\end{array}$ \\
\hline Summer $P$ & $\begin{array}{l}-0.05 \\
(p=0.72)\end{array}$ & $\begin{array}{l}-0.09 \\
(p=0.55)\end{array}$ & $\begin{array}{l}-0.13 \\
(p=0.32)\end{array}$ & $\begin{array}{l}-0.15 \\
(p=0.55)\end{array}$ & $\begin{array}{l}0 \\
(p=0.99)\end{array}$ & $\begin{array}{l}-0.03 \\
(p=0.98)\end{array}$ \\
\hline Fall $P$ & $\begin{array}{l}-0.05 \\
(p=0.72)\end{array}$ & $\begin{array}{l}-0.09 \\
(p=0.55)\end{array}$ & $\begin{array}{l}-0.36^{*} \\
(p=0.01)\end{array}$ & $\begin{array}{l}-0.55^{*} \\
(p<0.01)\end{array}$ & $\begin{array}{l}0.03 \\
(p=0.88)\end{array}$ & $\begin{array}{l}-0.04 \\
(p=0.85)\end{array}$ \\
\hline Annual $E$ & $\begin{array}{l}-0.03 \\
(p=0.78)\end{array}$ & $\begin{array}{l}-0.04 \\
(p=0.72)\end{array}$ & $\begin{array}{l}-0.21 \\
(p=0.10)\end{array}$ & $\begin{array}{l}-0.28 \\
(p=0.16)\end{array}$ & $\begin{array}{l}0.08 \\
(p=0.48)\end{array}$ & $\begin{array}{l}0.10 \\
(p=0.50)\end{array}$ \\
\hline Annual Pe & $\begin{array}{l}-0.13 \\
(p=0.17)\end{array}$ & $\begin{array}{l}-0.20 \\
(p=0.18)\end{array}$ & $\begin{array}{l}-0.13 \\
(p=0.32)\end{array}$ & $\begin{array}{l}-0.16 \\
(p=0.48)\end{array}$ & $\begin{array}{l}0.02 \\
(p=0.88)\end{array}$ & $\begin{array}{l}0 \\
(p=0.99)\end{array}$ \\
\hline Annual 7-day low flow & $\begin{array}{l}0.15 \\
(p=0.15)\end{array}$ & $\begin{array}{l}0.20 \\
(p=0.18)\end{array}$ & $\begin{array}{l}-0.09 \\
(p=0.50)\end{array}$ & $\begin{array}{l}-0.18 \\
(p=0.35)\end{array}$ & $\begin{array}{l}0.21 \\
(p=0.10)\end{array}$ & $\begin{array}{l}0.24 \\
(p=0.22)\end{array}$ \\
\hline
\end{tabular}

* Significant at $\alpha=0.05$.

Table 2. Cross-correlation between hydrological variables and ECA.

\begin{tabular}{llll}
\hline \multirow{2}{*}{ Hydrological variables } & \multicolumn{3}{c}{ Lag } \\
\cline { 2 - 4 } & 0 & -1 & -2 \\
\hline Annual mean flow & $0.19(p=0.25)$ & $0.34^{*}(p=0.05)$ & $0.19(p=0.25)$ \\
Winter mean flow & $0.20(p=0.26)$ & $0.38^{*}(p=0.03)$ & $0.47^{*}(p<0.01)$ \\
Spring mean flow & $0.20(p=0.26)$ & $0.22(p=0.20)$ & $0.12(p=0.39)$ \\
Summer mean flow & $0.17(p=0.36)$ & $0.05(p=0.60)$ & $0.10(p=0.46)$ \\
Fall mean flow & $0.24(p=0.16)$ & $0.47^{*}(p<0.01)$ & $0.09(p=0.50)$ \\
Annual 7-day low flow & $0.10(p=0.46)$ & $0.50^{*}(p<0.01)$ & $0.08(p=0.56)$ \\
\hline
\end{tabular}

* Significant at $\alpha=0.05$; ARIMA model for ECA $(1,1,1)$ non-constant.

forest disturbance on annual mean flow went upwards with increasing ECA, while that of climate variability declined over time. In Phase $1,84.9 \%$ of the variation in annual mean flow was explained by climate variability and only $15.1 \%$ of that was accounted by forest disturbance. During Phase 2, the relative contribution of forest disturbance on annual mean flow variation $\left(R_{\mathrm{f}}\right)$ climbed to $40.9 \%$, compared with $59.1 \%$ of variation explained by climate variability. In Phase 3, the relative contribution of forest disturbance went up to $57.7 \%$, while that of climate variability dropped to $42.3 \%$. In short, climate variability produced greater impact on annual mean flow than forest disturbance in Phases 1 and 2, while forest disturbance became more influential in Phase 3.
Table 3. Statistical tests of change in the slope of MDMC.

\begin{tabular}{|c|c|c|c|}
\hline \multicolumn{2}{|c|}{ CUSUM Control Chart } & \multicolumn{2}{|c|}{ Mann-Whitney U-test } \\
\hline Change point & Bootstrap times & Step change & Statistics Z \\
\hline $\begin{array}{l}1999^{*} \\
(p=0.04)\end{array}$ & 5000 & $1999^{*}$ & $\begin{array}{l}-3.03 \\
(p<0.01)\end{array}$ \\
\hline
\end{tabular}

* Significant at $\alpha=0.05$. 
Table 4. Annual mean flow deviation and its components in different phases.

\begin{tabular}{llllllll}
\hline Period & $\begin{array}{l}\Delta Q \\
(\mathrm{~mm})\end{array}$ & $\begin{array}{l}\Delta Q_{\mathrm{f}} \\
(\mathrm{mm})\end{array}$ & $\begin{array}{l}\Delta Q_{\mathrm{c}} \\
(\mathrm{mm})\end{array}$ & $\begin{array}{l}\Delta Q / Q \\
(\%)\end{array}$ & $\begin{array}{l}\Delta Q_{\mathrm{f}} / Q \\
(\%)\end{array}$ & $\begin{array}{l}\Delta Q_{\mathrm{c}} / Q \\
(\%)\end{array}$ & $\begin{array}{l}\mathrm{ECA} \\
(\%)\end{array}$ \\
\hline Phase 1: 1964-1989 & -5.7 & $-0.8 \pm 5.3$ & $-4.8 \pm 5.3$ & -5.5 & $-0.8 \pm 5.2$ & $-4.7 \pm 5.2$ & 3.7 \\
Phase 2: 1990-1998 & -4.2 & $9.2 \pm 4.8$ & $-13.3 \pm 4.8$ & -4.0 & $8.9 \pm 4.7$ & $-12.9 \pm 4.7$ & 15 \\
Phase 3: 1999-2009 & 9.7 & $48.4 \pm 4.3$ & $-35.5 \pm 3.9$ & 0.4 & $46.9 \pm 4.1$ & $-34.4 \pm 3.8$ & 35 \\
\hline
\end{tabular}

$Q$ : average annual mean flow from 1964 to 2009 (103.3 mm).

Table 5. The relative contributions of forest disturbance and climate variability on annual mean flow variation.

\begin{tabular}{lrrrr}
\hline Period & $\Delta Q(\mathrm{~mm})$ & $R_{\mathrm{f}}(\%)$ & $R_{\mathrm{c}}(\%)$ & ECA $(\%)$ \\
\hline Phase 1: 1964-1989 & -4.1 & 15.1 & 84.9 & 3.7 \\
Phase 2: 1990-1998 & -4.2 & 40.9 & 59.1 & 15 \\
Phase 3: 1999-2009 & 9.7 & 57.7 & 42.3 & 35 \\
\hline
\end{tabular}

$R_{\mathrm{f}}=100 \cdot\left|\Delta Q_{\mathrm{f}}\right| /\left(\left|\Delta Q_{\mathrm{f}}\right|+\left|\Delta Q_{\mathrm{c}}\right|\right) ; R_{\mathrm{c}}=100 \cdot\left|\Delta Q_{\mathrm{c}}\right| /\left(\left|\Delta Q_{\mathrm{f}}\right|+\left|\Delta Q_{\mathrm{c}}\right|\right)$.

\section{Discussion}

\subsection{Thresholds of forest disturbance for significant hydrological changes}

Since watersheds always have the ability to buffer changes caused by disturbances, there must be a theoretical threshold of forest disturbance level, below which significant change on hydrology may not be detected. Identification of forest disturbance thresholds is useful for guiding forest management practices to protect water resources and public safety. Efforts have already been made to determine the thresholds of forest logging in small watersheds. Such thresholds tend to be variable due to differences in topography, vegetation, geology, hydrological regime, and climate. For example, in the Appalachian Mountains of the United States, only $10 \%$ reduction in forest cover can produce a detectable response in annual mean flow (Swank et al., 1988), while in the Central Plains of the United States, $50 \%$ harvest might be required for a significant change in flow (Stednick, 1996). Generally, it is believed that more than $20 \%$ of the watershed area must be changed or disturbed to detect a significant change in streamflow in small watersheds (Bosch and Hewlett, 1982; Hetherington, 1987).

In comparison with small watersheds, the forest disturbance threshold for significant streamflow responses in large watersheds is likely more variable and difficult to generalize due to the greater complexity of topographies, land forms, and spatial patterns. For example, in the Baker Creek watershed (this study), with about $62.2 \%$ ECA, a significant change in annual mean flow was detected. Similarly, in the Willow River watershed, adjacent to our study watershed, logging of about $30 \%$ of the watershed (watershed area: $2860 \mathrm{~km}^{2}$ ) caused a significant increase in annual mean flow (Lin and Wei, 2008; Wei and Zhang, 2010b). Costa et al. (2003) found that in the Tocaintins River watershed $\left(175360 \mathrm{~km}^{2}\right)$, Brazil, only $19 \%$ reduction in forest cover produced a significant increase in annual mean flow. In contrast, Wei and Davidson (1998) did not detect significant change in annual mean flow in the Bowron River watershed $\left(3420 \mathrm{~km}^{2}\right)$, the watershed adjacent to the Willow River watershed mentioned above, although $30 \%$ of the watershed had been harvested. The study from Buttle and Metcalfe (2000) failed to find definitive changes in annual mean flow with disturbance levels ranging from 5 to $25 \%$ of watersheds (from 401 to $11900 \mathrm{~km}^{2}$ ) in Canadian boreal forests. Additionally, even with forest cover reduced by $53 \%$, no significant hydrological change was identified in the Nam Pong River Basin (12 $100 \mathrm{~km}^{2}$ ), Northeast Thailand (Wilk et al., 2001). Those contrasting results clearly suggest that forest disturbance threshold is likely watershed specific. It also demonstrates a need for more case studies in large watersheds before generalized conclusions can be derived.

\subsection{Forest disturbance effect on mean flows}

With ECA over $60 \%$, annual mean flow was significantly increased by $46.9 \%$ on average after forest disturbance, as suggested by both correlation analysis and MDMC. This is consistent with the previous modeling work by Alila et al. (2007) in the Baker Creek watershed, where, with $34 \%$ of the watershed harvested, annual mean flow was estimated to be increased by $31 \%$. However, the change magnitudes are different. The difference in hydrological responses between the two studies may be explained by their different research approaches and different disturbance levels.

Our analysis shows that during the severe disturbance period from 1999-2009, when ECA increased from $19.2 \%$ to $62.2 \%$, the average increment in annual mean flow caused by forest disturbance was $48.4 \mathrm{~mm}$, which is about a $12 \mathrm{~mm}$ increment in annual mean flow for each $10 \%$ increase in ECA. The change in magnitude is lower than that from an adjacent watershed, the Willow River watershed (watershed size: $2860 \mathrm{~km}^{2}$ ), where each $10 \%$ increase in ECA can result in about a $23 \mathrm{~mm}$ increment in annual mean flow (Wei and Zhang, 2010b). The positive responses of annual mean flow to forest disturbance in both the Baker and Willow watersheds are within the range of responses in the small watershed studies in the Pacific Northwest (2.5 to $30 \mathrm{~mm}$ increment in annual mean flow for each $10 \%$ increase in harvested 
area) (Moore and Wondzell, 2005). However, the relative change in long-term annual mean flow in the Baker Creek watershed is much higher than that in the Willow River watershed. On average, with an ECA of $62.2 \%$, annual mean flow is increased by $46.9 \%$ in the Baker Creek watershed, while the increment in the Willow River watershed is only $9.8 \%$ with an ECA of $29.4 \%$ (Wei and Zhang, 2010b). This suggests that the hydrological response to forest disturbance in the Baker Creek watershed is more sensitive than that in the Willow River watershed. The difference in the magnitude of annual mean flow may be responsible for different hydrological responses in the two neighbouring watersheds. The annual mean flow in the Baker Creek watershed was only $103 \mathrm{~mm}$, while it was $435 \mathrm{~mm}$ in the Willow River watershed. For example, a $20 \mathrm{~mm}$ increment can increase the annual mean flow in the Baker Creek watershed by about $20 \%$, while it can only cause less than $5 \%$ change in annual mean flow in the Willow River watershed.

There are limited large watershed studies on quantification of the hydrological impacts of forest disturbance, and change of magnitude in annual mean flow is highly variable, ranging from $4 \%$ to $136 \%$. The study from the interior Columbia River basin $\left(567000 \mathrm{~km}^{2}\right)$ disclosed that $27 \%$ land cover change resulted in only $4.2-10.5 \%$ increment in annual mean flow (Matheussen et al., 2000), while in the Great Lakes basin $\left(494000 \mathrm{~km}^{2}\right)$ annual mean flow was augmented by up to $136 \%$ as a result of only $17 \%$ land cover change (Mao and Cherkauer, 2009). Clearly, more large watershed studies are needed to draw any reliable conclusions on the annual mean flow change of magnitude caused by forest disturbance or land cover change.

\subsection{Forest disturbance effect on low flows}

The correlation analysis showed that forest disturbance significantly increased annual low flow and dry season (fall and winter) mean flow. This is in accordance with some smallscale studies from snowmelt dominated watersheds (Van Haveren, 1988; Gottfried, 1991) and the majority of studies from rainfall dominated watersheds (Bari et al., 1996; Bent, 2001; Robinson and Dupeyrat, 2005; Webb et al., 2007). Since removal or death of forests can decrease evapotranspiration and interception in disturbed sites, these disturbances ultimately increase soil moisture and groundwater recharge (Bosch and Hewlett, 1982). Hence, discharges to the streams from groundwater and channel banks tend to increase in dry and low flow seasons.

However, no changes or decreases in dry season flow or low flow have also been reported after forest disturbance (Bruijnzeel, 2004; Calder, 2005). Many factors such as soil infiltration characteristics, regional aquifer characteristics, vegetation distribution, climate, and human activities control low flow generation (Smakhtin, 2001). The degree of soil disturbance after logging or wildfire is regarded as an important indicator for low flow response. When the soil characteristics are severely affected by forest disturbance, for example via soil compaction by heavy machinery of logging or soil hydrophobization after fire, soil infiltration capacity can be severely impaired, leading to more surface runoff and, consequently, less recharge to deep soil and groundwater systems. As a result, dry season flows or low flows are expected to be less or unchanged. Moreover, removal of cloud forests in some coastal watersheds, where fog drip intercepted by forests serves as an important precipitation input, is likely to reduce low flows. This is because decreased fog drip after forest disturbance can lead to reduction of water input for streamflow and, consequently, declined low flows in summer (Harr, 1982).

Our study watershed is a snowmelt dominated watershed with low flows typically occurring from late summer through the winter until spring snowmelt. Forest logging in the interior of B.C. normally occurs in winter when soils are completely frozen, which may cause minor or insignificant damage to soils. Therefore, dry season flows or low flows are expected to increase as removal of forest reduces evapotranspiration and interception, resulting in more water available in the soils to promote soil infiltration and groundwater recharge. This may explain why there are significant changes in hydrology during low flow seasons in our study watershed.

\subsection{Off-setting effect of forest disturbance and climate variability on annual mean flow variation}

According to our analysis, forest disturbance and climatic variability produced opposite impacts on streamflow: forest disturbance increased streamflow while climatic variability decreased it. For example, during the severely disturbed period from 1999 to 2009 with ECA greater than $20 \%$, forest disturbance boosted annual mean flow, on average, by about $48.4 \mathrm{~mm} \mathrm{yr}^{-1}$, while climate variability reduced it by $35.5 \mathrm{~mm} \mathrm{yr}^{-1}$. Not surprisingly, their counteracting or cancelling effects meant that annual mean flow displayed a stable trend over the study period. Jones et al. (2012) also identified these counteracting effects of forest disturbance and climate variability by the thorough analyses of longterm records in 35 headwater basins in the United States and Canada. It suggests that forest ecosystems have the ability of adjusting their water use to compensate for climate variability.

Interestingly, the interactive influences of climatic variability and forest disturbance are dynamic over time with significantly increased forest disturbance. Prior to 1999 , with ECA less than $20 \%$, climate variability was more influential than forest disturbance. Before 1990, about $84.9 \%$ of variation in annual mean flow was accounted for by climate variability, and this percentage greatly declined to $42.3 \%$ during the severe disturbance period (1999-2009) with an average ECA of $35 \%$. In contrast, the contribution from forest disturbance to annual mean flow variation was minor during the early period when ECA was less than $10 \%$, and then 
increased significantly after 1998. Clearly, between 1999 and 2009 the influence on streamflow from forest disturbance exceeded that from climatic variability. This finding is different from a similar study in the Willow River watershed where climatic variability generally played a slightly more important role than forest disturbance did (Wei and Zhang, 2010b). The Willow River watershed was mainly disturbed by logging activities with ECA less than $30 \%$, while the Baker Creek watershed was attacked by large-scale MPB infestation and subsequent salvage logging with an ECA of $62 \%$. This high level of forest disturbance made it the major contributor to annual mean flow variation instead of climate variability. As a matter of fact, in many other large watersheds experiencing significant land-use changes, the influence of climate variability on streamflow appeared to be weaker. For example, in the headwaters of the Yellow River Basin, China, only $30 \%$ of the streamflow reduction in the 1990s was caused by climate variability, while land-use change was responsible for $70 \%$ of the reduction (Zheng et al., 2009). A similar result was also reported in the Chaobai River watershed, China, by Wang et al. (2009) and Zhang et al. (2008). Moreover, small watershed studies yielded similar findings too. Landuse changes or forest disturbances are believed to mitigate or even overwhelm climatic effects on streamflow. For example, in three long-term experimental forests (Andrews, Coweeta, and Hubbard Brook) increments of daily streamflow in the late summer and early fall caused by forest harvest can be up to $300 \%$ in the early years after disturbance, while climate induced changes in streamflow can be $10-50 \%$ (Jones and Post, 2004).

In forest dominant watersheds, forest changes and climatic variability are commonly recognized as two major drivers for hydrological changes. Understanding their interactive, dynamic effects is important for sustainable water management, protection of ecosystem functions, and public safety. In our study watershed, the effects of climatic variability and forest disturbance were offsetting over the study period because the dry climate trend reduced streamflow while forest disturbance increased it. This offsetting effect can help buffer hydrological alteration. In some dry, small watersheds in the United States, no trends in streamflow have been identified with global warming (Jones et al., 2012). However, the effects of climatic variability and forest disturbance can be cumulatively added if the effects are in the same direction. For example, if climate displayed a wetting trend, then increasing streamflow resulting from climatic variability could further augment higher river discharge caused by more forest disturbance, and consequently lead to higher risk of floods. To maintain a healthy watershed, the level of forest disturbance or land-use change should be carefully designed so that their negative impacts on aquatic functions can be minimized.

\subsection{Implication for watershed management}

Severe forest disturbances have produced significant hydrological impact in the Baker Creek watershed. Annual mean flow has been increased by $47.6 \%$, and dry season mean flow has also been significantly augmented. From the water supply perspective, these increases can be positive and substantial, particularly for this relatively dry watershed. The average annual mean flow in our study watershed was only $103.3 \mathrm{~mm}$ with great inter-annual variability, suggesting that water supply is likely constrained or stressed, especially in the dry seasons from late summer to winter. The positive effect of forest disturbance on streamflow will certainly help alleviate the water supply stress within the watershed and downstream of the watershed. However, such a positive effect will be gradually diminished with forest regeneration over time. Resource managers must recognize this dynamic, positive effect and incorporate it into the design of sustainable water management.

Forest disturbance and climate variability have counteracting effect on streamflow, which helps maintain a stable water supply system. However, as forest disturbance becomes more severe, the impact of forest disturbance on hydrology tends to override the influence from climate variability, which possibly breaks the inherent balance of the aquatic system. For example, severe forest disturbance can dramatically increase soil erosion and impose negative impacts on aquatic habitats due to increased water temperature and sediments. Under this circumstance, forest disturbance may cause irreversible change in aquatic ecosystems and eventually damage watershed ecological functions. Therefore, it is critical to constrain forest disturbance to a safe level so that negative effects can be minimized.

Our analysis suggests that dry season flows or low flows have been significantly increased by forest disturbance. This finding is important for water allocation and fish habitat conservation. As mentioned before, increased dry season flows or low flows may reduce drought risks and enhance water supply from late summers through winters. On the other hand, these changes may affect aquatic habitat. For example, salmon migrate from the Pacific Ocean to the upper reaches and tributaries of Fraser River to spawn in dry seasons. Significantly increased flow in dry seasons may affect salmon migration and spawning due to alteration of flow magnitude and associated water quality. More research is needed to further explore the potential impacts of low flow change on aquatic ecosystems.

\section{Conclusions}

Severe forest disturbances such as large-scale MPB infestation and subsequent salvage logging have significantly increased annual mean and low flows in the Baker Creek watershed. The influence of forest disturbance on hydrology 
exceeded that from climatic variability when forest disturbance level in terms of ECA was up to $62.2 \%$ in the watershed. These findings are of great importance to water resource planning and aquatic habitats protection. Although the increments in annual mean flow and dry season flow have positive effects on water supply and can alleviate water stress in this dry watershed, their impacts on aquatic habitat and other aquatic functions remain uncertain. This result can be useful for hydrological modeling studies.

Acknowledgements. Thanks for the constructive comments from two anonymous reviewers. P. Zhou helped in ECA calculation.

Edited by: J. Liu

\section{References}

Alila, Y., Chatwin, S., and Luo, C.: An application of the DHSVM model to estimating the impact of mountain pine beetle attack and salvage harvesting on stream flows, in: Mountain Pine Beetle and Watershed Hydrology Workshop: Preliminary Results of Research from BC, Alberta and Colorado, edited by: Redding, T., Kelowna, Canada, 45-46, 2007.

Bari, M. A., Smith, N., Ruprecht, J. K., and Boyd, B. W.: Changes in streamflow components following logging and regeneration in the southern forest of Western Australia, Hydrol. Process, 10, 447-461, 1996.

Barnard, G. A.: Control charts and stochastic processes, J. Roy. Stat. Soc. B Met., 21, 239-71, 1959.

Bent, G. C: Effects of forest-management activities on runoff components and ground-water recharge to Quabbin Reservoir, central Massachusetts, Forest Ecol. Manag., 143, 115-129, 2001.

Berryman, D., Bobêe, B., Cluis, D., and Haemmerli, J.: Nonparametric tests for trend detection in water quality time series, Water Resour. Bull., 24, 545-556, 1988.

Blöschl, G., Ardoin-Bardin, Bonell, M., Dorninger, M., Goodrich, D., Gutknecht, D., Matamoros, D., Merz, B., Shand, P., and Szolgay, J.:At what scales do climate variability and land cover change impact on flooding and low flows?, Hydrol. Process, 21, 1241-1247, 2007.

Bosch, J. M. and Hewlett, J. D.: A review of catchment experiments to determine the effect of vegetation changes on water yield and evapotranspiration, J. Hydrol., 55, 3-23, 1982.

British Columbia Ministry of Forests and Rangeland: Interior Watershed Assessment Guidebook (Appendix 8) 2nd Edn., Victoria, British Columbia, Canada, 1999.

British Columbia Ministry of Forests and Rangeland: Map of Biogeoclimatic Zones of British Columbia, Victoria, British Columbia, Canada, available at: http://www.for.gov.bc.ca/hre/ becweb/resources/maps/ProvinceWideMaps.html (last access: 25 May 2012), 2012.

Bruijnzeel, L.: Hydrological functions of tropical forests: not seeing the soil for the trees?, Agr. Ecosyst. Environ., 104, 185-228, 2004.

Burn, D. and Hag Elnur, M.: Detection of hydrologic trends and variability, J. Hydrol., 255, 107-122, 2002.
Buttle, J. and Metcalfe, R.: Boreal forest disturbance and streamflow response, northeastern Ontario, Can. J. Fish. Aquat. Sci., 57, 5-18, 2000.

Calder, I. R.: Blue revolution - integrated land and water resources management, 2nd Edn., Earthscan, London, UK, 2005.

Chen, W. and Wei, X.: Assessing the relations between aquatic habitat indicators and forest harvesting at watershed scale in the interior of British Columbia, Forest. Ecol. Manag., 256, 152-160, 2008.

Costa, M. H., Botta, A., and Cardille, J. A.: Effects of large-scale changes in land cover on the discharge of the Tocantins River, Southeastern Amazonia, J. Hydrol, 283, 206-217, 2003.

Donohue, R. J., Roderick, M. L., and McVicar, T. R.: On the importance of including vegetation dynamics in Budyko's hydrological model, Hydrol. Earth Syst. Sci., 11, 983-995, doi:10.5194/hess11-983-2007, 2007.

Fleming, S. W., Whitfield, P. H., Moore, R. D., and Quilty, E. J.: Regime-dependent streamflow sensitivities to Pacific climate modes cross the Georgia-Puget transboundary ecoregion, Hydrol. Processes, 21, 3264-3287, doi:10.1002/hyp.6544, 2007.

Gottfried, G. J.: Moderate timber harvesting increases water yields from an Arizona mixed conifer watershed, Water Resour. Bull., 27, 537-547, 1991.

Hargreaves, G. and Samani, Z.: Reference crop evapotranspiration from temperature, Appl. Eng. Agric., 1, 96-99, 1985.

Harr, R. D.: Fog Drip in the Bull Run Municipal Watershed, Oregon, Water Resour. Bull., 18, 785-789, 1982.

Hetherington, E. D.: The importance of forests in the hydrological regime, in: Canadian Bulletin Fisheries and Aquatic Sciences, edited by: Healy, M. D. and Wallace, R. R., Ottawa, Ont., No. 215, 533 pp., 1987.

Hudson, R.: Snowpack recovery in regenerating coastal British Columbia clearcuts, Can. J. Forest Res., 30, 548-556, doi:10.1139/cjfr-30-4-548, 2000.

Jassby, A. D. and Powell, T. M.: Detecting Changes in Ecological Time Series, Ecology, 71, 2044-2052, 1990.

Jost, G., Moore, R. D., Weiler, M., and Alila, Y.: A Combined Statistical and Mechanistic Modeling Approach to Study the Effect of Clear-cutting in a Snow Dominated Watershed, in: Proceedings of the American Geophysical Union Fall Meeting, San Francisco, 15-19 December, 2008.

Jones, J. A. and Post, D. A.: Seasonal and successional streamflow response to forest cutting and regrowth in the northwest and eastern United States, Water Resour. Res., 40, W05203, doi:10.1029/2003WR002952, 2004.

Jones, J. A., Creed, I. F., Hatcher, K. L., Warren, R. J., Adams, M. B., Benson, M. H., Boose, E., Brown, W. A., Campbell, J. L., Covich, A., Clow, D. W., Dahm, C. N., Elder, K., Ford, C. R., Grimm, N. B., Henshaw, D. L., Larson, K. L., Miles, E. S., Miles, K. M., Sebestyen, S. D., Spargo, A. T., Stone, A. B., Vose, J. M., and Williams, M. W.: Ecosystem Processes and Human Influences Regulate Streamflow Response to Climate Change at Long-Term Ecological Research Sites, Bioscience, 62, 390-404, doi:10.1525/bio.2012.62.4.10, 2012

Juckem, P. F., Hunt, R. J., Anderson, M. P., and Robertson, D. M.: Effects of climate and land management change on streamflow in the driftless area of Wisconsin, J. Hydrol., 355, 123-130, 2008.

Kiffney, P., Bull, J. P., and Feller, M. C.: Climatic and hydrologic variability in a coastal watershed of southwestern 
British Columbia, J. Am. Water Resour. As., 38, 1437-1451, doi:10.1111/j.1752-1688.2002.tb04357.x, 2002.

Lewis, D. and Huggard, D.: A model to quantify effects of mountain pine beetle on equivalent clearcut area, Streamline Watershed Manag. Bull., 13, 42-51, 2010.

Li, L., Zhang, L., Wang, H., Wang, J., Yang, J., Jiang, D., Li, J., and Qin, D.: Assessing the impact of climate variability and human activities on streamflow from the Wuding River basin in China, Hydrol. Process., 21, 3485-3491, doi:10.1002/hyp.6485, 2007.

Lin, Y. and Wei, X.: The impact of large-scale forest harvesting on hydrology in the Willow watershed of Central British Columbia, J. Hydrol., 359, 141-149, 2008.

Ma, X., Xu, J., and van Noordwijk, M.: Sensitivity of streamflow from a Himalayan catchment to plausible changes in land cover and climate, Hydrol. Process., 24, 1379-1390, 2010.

Mantua, N. and Hare, S.: The Pacific Decadal Oscillation, J. Oceanogr., 58, 35-44, doi:10.1023/A:1015820616384, 2002.

Mao, D. and Cherkaue, K. A.: Impacts of land-use change on hydrologic responses in the Great Lakes region, J. Hydrol., 374, 71-82, 2009.

Matheussen, B., Kirschbaum, R. L., Goodman, I. A., O’Donnell, G. M., and Lettenmaier, D. P.: Effects of land cover change on streamflow in the interior Columbia River Basin (USA and Canada), Hydrol. Process., 14, 867-885, 2000.

Mbogga, M., Hamann, A., and Wang, T.: Historical and projected climate data for natural resource management in western Canada, Agr. Forest Meteorol., 149, 881-890, 2009.

McCabe, G. and Wolock, D.: A step increase in streamflow in the conterminous United States, Geophys. Res. Lett., 29, 38-31, doi:10.1029/2002GL015999, 2002.

Mitchell, T. D. and Jones, P. D.: An improved method of constructing a database of monthly climate observations and associated high-resolution grids, Int. J. Climatol., 25, 693-712, 2005.

Moore, R. and Wondzell, S.: Physical hydrology and the effects of forest harvesting in the Pacific Northwest: a review, J. Am. Water Resour. As., 41, 763-784, 2005.

Neary, D. G., Gottfried, G. J., and Ffolliott, P. E.: Post-wildfire watershed flood response, in: Proceedings of the 2nd International Fire Ecology Conference, Orlando, Florida, 16-20 November, Paper 1 B.7, 2003.

Oudin, L., Andréassian, V., Lerat, J., and Michel, C.: Has land cover a significant impact on mean annual streamflow? An international assessment using 1508 catchments, J. Hydrol., 357, 303316, 2008.

Ring, P. J. and Fisher, I. H.: The effects of changes in land use on runoff from large catchments in the upper Macintyre Valley, NSW, in: Hydrology and Water Resources Symposium, Sydney, 14-16 May 1985, The Institution of Engineers, Australia, National Conference Publication 85/2, 153-158, 1985.

Robinson, M. and Dupeyrat, A.: Effects of commercial timber harvesting on streamflow regimes in the Plynlimon catchments, mid-Wales, Hydrol. Process, 19, 1213-1226, 2005.

Sankarasubramanian, A., Vogel, R. M., and Limbrunner, J. F.: Climate elasticity of streamflow in the United States, Water Resour. Res., 37, 1771-1781, 2001.

Sharma, K. P., Vorosmarty, C. J., and Moore, B.: Sensitivity of the Himalayan hydrology to land-use and climatic changes, Climatic Change, 47, 117-139, 2000.
Shuttleworth, W. J.: Evaporation, in: Handbook of Hydrology, edited by: Maidment, D. R., McGraw-Hill, New York, 4.1-4.53, 1993.

Siegel, S.: Nonparametric statistics, Am. Stat., 11, 13-19, 1957.

Smakhtin, V. U.: Low flow hydrology: a review, J. Hydrol., 240, 147-186, 2001.

St. Jacques, J. M., Sauchyn, D. J, and Zhao, Y.: Northern Rocky Mountain streamflow records: Global warming trends, human impacts or natural variability?, Geophys. Res. Lett., 37, L06407, doi:10.1029/2009GL042045, 2010.

Stednick, J. D.: Monitoring the effects of timber harvest on annual water yield, J. Hydrol., 176, 79-95, 1996.

Swank, W. T., Swift, J. R., and Douglas, J. E.: Streamflow changes associated with forest cutting, species conversion and natural disturbance, in: Forest Hydrology and Ecology at Coweeta, Ecological Studies 66, edited by: Swank, W. T. and Crossley, D. A., Springer, New York, 297-312, 1988.

Talbot, J. and Plamondon, A. P.: The diminution of snowmelt rate with forest regrowth as an index of peak flow hydrologic recovery, Montmorency Forest, Quebec, in: Proceedings of the 59th Eastern Snow Conference, Stowe, Vermont, USA, 2002.

Tuteja, N. K., Vaze, J., Teng, J., and Mutendeudzi, M.: Partitioning the effects of pine plantations and climate variability on runoff from a large catchment in southeastern Australia, Water Resour. Res., 43, W08415, doi:10.1029/2006WR005016, 2007.

Van Haveren, B. P.: A Reevaluation of the Wagon Wheel Gap Forest Watershed Experiment, Forest Sci., 34, 208-214, 1988.

Vose, J. M., Sun, G., Ford, C. R., Bredemeier, M., Otsuki, K., Wei, X., Zhang, Z., and Zhang, L.: Forest ecohydrological research in the 21 st century: what are the critical needs?, Ecohydrology, 4, 146-158, 2011.

Wang, G., Xia, J., and Chen, J.: Quantification of effects of climate variations and human activities on runoff by a monthly water balance model: A case study of the Chaobai River basin in northern China, Water Resour. Res., 45, W00A11, doi:10.1029/2007WR006768, 2009.

Webb, A., Jarrett, B., and Turner, L.: Effects of plantation forest harvesting on water quality and quantity: Canobolas State Forest, NSW, in: Proceedings of the 5th Australian Stream Management Conference, Australian Rivers: Making a Difference, edited by: Wilson, A., Deehan, R., Watts, R., Page, K., Bownan, K., and Curtis, A., Charles Sturt University, Thurgoona, Australia, 2007.

Wei, A. and Davidson, G.: Impacts of large scale timber harvesting on the hydrology of the Bowron River Watershed, in: Proceedings of the 51st Annual CWRA Conference, Mountains to Sea: Human Interaction with the Hydrologic Cycle, Victoria, Canada, 10-12 June, 45-52, 1998.

Wei, X. and Zhang, M.: Research methods for assessing the impacts of forest disturbance on hydrology at large-scale watersheds, in: Landscape Ecology and Forest Management: Challenges and Solutions in a Changing Globe, edited by: Chen, J., Chao, L., and Lafortezza, R., Springer-Verlag, Berlin Heidelberg, Germany, 119-147, 2010a.

Wei, X. and Zhang, M.: Quantifying streamflow change caused by forest disturbance at a large spatial scale: A single watershed study, Water Resour. Res., 46, W12525, doi:10.1029/2010WR009250, 2010b.

Whitaker, A., Alila, Y., Beckers, J., and Toews, D.: Evaluating peak flow sensitivity to clear-cutting in different elevation bands of 
a snowmelt-dominated mountainous catchment, Water Resour. Res., 38, 1172, doi:10.1029/2001WR000514, 2002.

Wilk, J., Andersson, L., and Plermkamon, V.: Hydrological impacts of forest conversion to agriculture in a large river basin in northeast Thailand, Hydrol. Process., 15, 2729-2748, 2001.

Winkler, R. D., Spittlehouse, D. L., and Golding, D. L.: Measured differences in snow accumulation and melt among clearcut, juvenile, and mature forests in southern British Columbia, Hydrol. Process., 19, 51-62, 2005.

Winkler, R. D., Rex, J. F., Teti, P., Maloney, D. A., and Redding, T.: Mountain pine beetle, forest practices, and watershed management, B.C. Min. For. Range, Res. Br., Victoria, B.C. Exten. Note No. 88, available at: www.for.gov.bc.ca/hfd/pubs/Docs/En/En88. pdf (last access: March 2010), 2008.

Zégre, N., Skaugset, A. E., Som, N. A., McDonnell, J. J., and Ganio, L. M.: In lieu of the paired catchment approach: Hydrologic model change detection at the catchment scale, Water Resour. Res., 46, W11544, doi:10.1029/2009WR008601, 2010.
Zhang, L., Dawes, W. R., and Walker, G. R.: Response of mean annual evapotranspiration to vegetation changes at catchment scale, Water Resour. Res., 37, 701-708, 2001.

Zhang, X., Zhang, L., Zhao, J., Rustomji, P., and Hairsine, P.: Responses of streamflow to changes in climate and land use/cover in the Loess Plateau, China, Water Resour. Res., 44, W00A07, doi:10.1029/2007WR006711, 2008.

Zhao, F., Zhang, L., Xu, Z., and Scott, D. F.: Evaluation of methods for estimating the effects of vegetation change and climate variability on streamflow, Water Resour. Res., 46, W03505, doi:10.1029/2009WR007702, 2010.

Zheng, H., Zhang, L., Zhu, R., Liu, C., Sato, Y., and Fukushima, Y.: Responses of streamflow to climate and land surface change in the headwaters of the Yellow River Basin, Water Resour. Res., 45, W00A19, doi:10.1029/2007WR006665, 2009.

Zhou, G., Wei, X., Luo, Y., Zhang, M., Li, Y., Qiao, Y., Liu, H., and Wang, C.: Forest recovery and river discharge at the regional scale of Guangdong Province, China, Water Resour. Res., 46, W09503, doi:10.1029/2009WR008829, 2010. 